\title{
Media Culture and Media Education in Modern School
}

\author{
MirelaTolić \\ Faculty of Philosophy, Department of Education, University of Split \\ Sinjska 2, 21000 Split, Croatia \\ Tel: 385-386-122, 385-490-280Ｆax: 385-329-288Ｅ-mail: mtolic@ffst.hr
}

\author{
Received: May 2, $2011 \quad$ Accepted: May 30, $2011 \quad$ Published: October 1, 2011 \\ doi:10.5430/wje.v1n2p89 URL: http://dx.doi.org/10.5430/wje.v1n2p89
}

\begin{abstract}
Culture is no longer conceivable without the media and / or new phenomena called. "Cyber" culture. The article discusses issues in what respect the different media, like Tv, film and Internet are with different cultures, how it changes everyday life under influence of various forms of sophisticated communications media and what competencies have children and young people, teachers, professional staff and parents to acquire know the "deal" with the new challenges in education? The article presents new aspects of the analysis of relations beetwen media culture and media education. The author analyzes the relationship of media culture and media education explains the transformation of homo communicans in homo socius. Media culture is analyzed in interaction with the development of media pedagogy. He points out the importance of etymological analysis Bourdie's understanding of philosophy of symbolic forms, cultural studies, the Frankfurt School and Luhmann's understanding of communication theory for the development of media culture in the "cyber society". Assumes that it is necessary for their development of meaningful relationships reflexive-critical attitude towards the accelerated development of new media for the preservation of culture and identidy school students. The article offers practical guidance for the development of media culture and media education into school curriculum.
\end{abstract}

Keywords: Media culture, Media education, School curriculum, Cultural studies, Communications, Communication identity

\section{Introduction}

Analysis of the media are very current in educational practice, not only in the educational process. Audiovisual (innovative) media: television and the internet, as well as traditional media, such as books, magazines and radio in the past few decades, given its importance in the analysis of their effects on the mindset of children and young people (Kellner, 1999, 344). With the development of the Internet puts great emphasis on the freedom of articulation, to freedom of opinion, but not enough to his pedagogical implication in education. The author actualizes the question of how the media influence the recipient (child-student and / or a parent, teacher) to perceive and interpret the symbolic message. New technologies are changing the habits and behavior of individuals, especially young people. Change of globalization through innovative media has ambivalent role. With the development of innovative media and the growing need for the development of media culture, especially in the process of education. Users of the media, (student, teacher and / or parents) can potentially decide for themselves whether they need a product for you. Media define a relationship in which identity is formed in a symbolic "game" kulturih factors. They include in particular the preferences of consumers of media associated with their own interests. All expressed the symbolic aspects of the needs imposed by the commercials, where they appear (exotic) pictures desire, beauty, success, etc. Advertisements, information and entertainment, fiction and the construction of reality mixed with the aesthetics and everyday culture. Media offers a formal and content is increasingly equated with human needs. This opens the field of media manipulation. (Miliša, 2006) users (children) are no longer invited to purchase the product, but to assume a new life style, the dominant ritual in which this product is accepted as an unavoidable part of life. Media propaganda is increasingly influences the lifestyles, as a product of the media industry. New media are increasingly creating new myths and stereotypes. The construction of personality and identity that is in the consumerist society turns into a double myth of satisfaction, while the myth of freedom of choice. Identity is created by the action of the so-called change. official culture and those presented in the media. Facilities are also "packaged" to look like part of everyday life. Media handlers to deal with the issue (pro) to find a "magical" solution to real problems. All this points to deeper thinking about the development of media culture and media education and its interaction in the school curriculum. However, the importance and development of media culture in Croatia is koncepted on obtaining knowledge (mostly) out of print, Internet, school newspapers and newspaper 
for teenagers, Theatre (youth), music, radio, TV, library, cinema, but not on methodical way, the question of how to "know" to resist the negative influence of media, or to acquire certain media competence. Media Culture in Croatia is seen as one that helps minded citizens, who may come in a variety of diverse information and messages, for example, to better understand the medium of film, its specificity, mode of expression (according to Media Research). At this approach is missing the importance of media education that seeks the acquisition of media competence. The development of media culture should be integrated with the Media Education. No media education, which implies the adoption of media competence can not be a media culture (itself) to develop core competencies.

\subsection{Young people and media and cultural process in terms of modernization}

In late 80th showed that the number and use of media leading to the construction of social identity and new social forms (Kellner, 1999). The dominant media culture affect communication exchange. New media have great influence on the economy, science, politics, culture, public and private. This means not only increase supply but the communication and the creation of new media offers and educational messages. The media play an important role in the constitution of socio-cultural differentiation, and influencing the world of youth and the formation of their identity. Media take over the function of the transformer and provide the "impetus" to the development of new cultural identities. With these modifications is related to perceptions of greater opportunities to select and define their own lifestyle. And there arise important consequences for the education of children and youth. Various media and programs provide a new choice. Plays a role, and the globalization process of youthful culture. Youthful musical styles led to the creation of a special "language", where young members of certain subculture indicate which group they belong. Merten (1994) defines culture as "a social system that works with very different forms of art and media, social understanding, which creates a social orientation and shaping identities. (Merten, 1994, 151). In this way, through the (different) media modeled by knowledgeable people, especially in terms of sense of symbols, the experience of the world and control in relation to the processes of enculturation and socialization.

Culture can be understood only as part of media culture, if it is understood as "social and socio-historical program for the harmonization of individual manufactured construction of reality" (Schmidt, 1994, 41) and also suppose that the functional differentiation in both societies the mass media have become a powerful part social interaction, then the culture is not necessarily manifested as a media culture, because "culture is implemented as a media culture and almost could be added as anything else" (Schmidt, 1994).

Analyze the cultural definition of Stuart Hall $(1993,2002)$ when he formulated as a sum of different classification systems and discursive formations, to make things give meaning and purpose. In this sense, culture could be included refers to the production of meaning. Culture, according to Foucault (1996) involved in the formation of discourse and discursive events, which are ultimately responsible for certain specific power relations and knowledge production. In this perspective, talking about the "popular media culture" (according to Antonio Gramsciu -1987). The starting point is a comprehensive understanding of the culture with which it tries to start the study of media culture outside the model of autonomous and coherent culture (Hall, 1993). Ernst Cassirer (2010) "sprayed" Mind the multitude of symbolic forms: language, myth, art, religion and science. He is not only a cognitive apparatus that constitutes reality, but the crowd called. "Cultural spheres" that constitute the various dimensions and reality (by: Žanić, 2008.109). To modern educators, philosophers, sociologists and media theorists, the term "sham" forms the basis of differentiation between the ontological and ontic approaches to the analysis of reality. It is reasonable to say that the world of mass and new media, or so. cyber space is constitutive of culture media for the understanding of cultural trends, the concept of reality, and then the world under the influence of mass communication. That, at the same time, does not mean that it was originally understood the reality, as they define old metaphysicians (Kant ... etc.), immediately suppressed and abolished the latter, the media reality. That's why "critique of reason" (Kant) becomes the Cassirer (2010) critique of culture. Culture Cassirer detected through a system of symbolic forms (Cassirer, 2010.23). The task is "a philosophical systematization of the spirit" to draw complex cultural forms in an organic unity (Cassirer, 2010.23). What connects all these forms of culture in the presence of the role they play in sign language and symbol.

"Code" means the cultural symbol system. One just becomes a creator of cultural production, or "homo socius" in the modern "cyber society" and / or so. digital culture (Kellner, 1999, 360). With this understanding it is necessary to examine the significance of relations: media-communication and the science of culture. Media, communications and culture form a large part of the research. In terms of impact on the humanities Frühwald Wolfgang, Hans Robert Jauß, Koselleck, Jürgen Mittelstraße and Burkhart Steinwachs already 1991st The predicted shift in scientific research and teaching. (Kellner, 1999, 350). Given the globalization of modern society, and growing interest in developing so-called. creating a "cyber-cultures" through the media culture (Kellner, 1999, 350). The process of communication in culture is determined by the relations: sender-receiver-coding - decoding. (Ungeheuer, 1982.294). 
In the work of social systems, Luhmann argues that the meaning of "coding" and "decode" messages that the media "carry" and / or symbolize. This position argues the thesis that "the media carriers symbolic message." (Luhmann, 1996) Decoding the symbolic message is important to prevent media manipulation, or as a necessary competence for the prevention of violence and media (Miliša, Tolic, 2009). At the heart of communication is the production of meaning. However, Schmidt (1994), Kellner (1999) and Luhmann (1996) did not explain the dysfunctional role of the media in raising children and youth. The computer is the medium through which information is processed, and that the transmitter / sender as subjects when it does not have (her) a central role in the technical sense. This is especially characteristic of children and young people, who do not suffice ambivalent about the role of the media. Manfred Fassler (2001) in his book Network states that "the position of speech through the media driven (or will move) from the fixation on the political and journalistic opinion-making system and process information on the constitutional role of socially-programmed electronic networks" (Fassler, 2001). This example can argue about the various organizational social disorder that are organized through the Internet (Miliša, 2010). I Kellner media culture explores the aspects of "society is a fundamental conflict" (Kellner, 1999, 171). As digital society (Digital Society) affects the individual? Fassler question of how different levels of communication can look like in practice and the intentions of digital networks (Fassler, 2001). Critical reflection is opened and the relationship between scientific theories, but not the pedagogical implications of this arises from the relativity of the whole system of general theories of communication that are not directly explore the conceptual content of the media on the education of children and young people. This can be confirmed with the hypothesis that violence in the media becomes violence in reality, when fiction becomes reality, or when "everything has its price and the value of nothing" (Miliša, 2006). But to explain it in detail, it is necessary to determine the main determinants and development of media culture with the media education.

\section{Media Culture: basic characteristics and different starting points}

Reckwitz (2005) Culture media was analyzed from the point, "meaning the media in a social context" (Reckwitz, 2005, 33). The media have always supported, deepening, but also changed the education and upbringing. Media culture is starting to explore the relationship between changes in communications integration and cultural conflicts (Hepp, Krotz, Thomas, 2009, 29). "Media Culture in Transition" is the name of the press conference in 2009. year, the German Society for Journalism and Media and Communication Sciences, where the theme was dealt with for many years with the communications and media-research study was to "shadow" (Hepp, Krotz, Thomas, 2009, 19). In that perspective, it is interesting only as an aesthetic dimensions of communication media and the media offer "(Hepp, Krotz, Thomas, 2009, 9). The focus is a broader understanding of media culture, (in all variants of the different concepts of culture), and the media culture should be understood as an overall phenomenon, which is specified at the level of media production, media content, their reception and appropriation, and (political) control, conflict and identification, in their diversity, conflict, and historical contextualization (Hepp, Krotz, Thomas, 2009.39). In this context, the authors Andreas Hepp, Marco Hoehne \& Jeffrey Wimmer, in his book Medienkultur in Transition provides an overview of different perspectives on understanding the development of media culture and its contribution to the study of school culture and its relation to media education (Hepp, Höhn, Wimmer, 2010, 44). Emil Loebl (1903) in his book "Culture and the media," explains how to formulate analytical journalism, while Hartmann (2008) and printed media are sublimated "cultural power". In the perspective of media theory to each culture appears as a media culture so that it is strongly influenced by the "dominant media". Therefore, the transformation of media culture, long-term process that can be analyzed along its profound changes. Implicitly implemented, these considerations also apply to areas of communication sciences and media education, which is not explicitly associated with the theory of media (Merten 1994). The cultural approach to media research primarily deals with the analysis of texts as cultural artifacts. Consequently, one of the main issues in this paper: how the pragmatic aspect of media culture (as part of media education in school curricula) as very important integrate aspects of the development of school culture?

Media culture and cultural industry transformed the culture and as such is necessarily the product of consumer society. It is associated with "social action." (Kellner, 1999, 342). It is the social contextualisation of a change of media culture, known as the "structural transformation of the public," Jurgen Habermas (Habermas, 1990).

In order to theoretically complex relationship between culture and social "action" could conceive of, media culture is understood as the realization mediatising cultural practices in social situations and in certain historical moments (Kellner, 1999, 342). These contributions reflect the social significance of media offer, highlight selected aspects of social activity in a culture where the media and everyday experiences associated with the issue in ways that are experiencing different aspects of modern communication in the creation of partnerships, relationships and friendships, modern games ... until politologycal aspects (Kellner, 1999, 342). May be inherent in communications and media-scientific theory to be understood as an attempt to take on such a specific base to develop a specific concept of media culture in communication theory, media pedagogy, and other theories about the media. It is crucial pedagogical dimensions of the 
media, which does not develop only through the media rather than through specific media messages (Krotz, 2007). The works of author Joshua Meyrowitza are of particular interest for understanding the necessity of development of media culture and media education. (Hepp, Höhn, Wimmer, 2010, 44). Meyrowitz (1987) attempts to link macroeconomic assumptions of classical theory of media with (empirical) social science micro-analysis in the tradition of symbolic interactionisme (Meyrowitz 1987). In this approach there is no media culture in the singular, rather than just different culture media. In accordance with the "process of civilization" viewed as a variety of media culture: "Beyond the traditional cultures with low internal differentiation following culture in which is inserted into a hierarchical process of differentiation." (Meyrowitz 1995, 57).

In the past few years in Europe has developed a specific branch of media theory in the presence of the concept of media culture with concepts of media theory and cultural studies. The establishment of such a theory of mediation can be considered as a response to the fact that more and more media "mediated" material and that the media are formatted in accordance with changes in different cultural contexts (Livingstone 2009). Knut Lundby is summed up by "mediation" as a central concept in order to understand the role of media in social change (Lundby, 2009: 1). In such a conceptual framework of media culture is understood as "mediated by culture," then as a culture in which technically mediated communication permeates many areas of society and is shaped by its symbolic forms. As a special sphere of this intervention is considered to be in the media everyday educational practice. Therefore, analysis of the impact of the media should provide preventive guidance on how to effectively resist manipulations.

\subsection{Different views on the development and understanding of media culture}

Frankfurts schools have a critical attitude when it comes to products of mass production of cultural industries. However, the weak point of the school's stance is that the role of the media too little understood, because the media manipulators "distorted" values represent a new trend manifestations of mass culture. It is therefore necessary to distinguish "media culture" of "mass culture", or - "popular culture" (Kellner, 1999, 346). The media have a double symbolic value: mplicitnu or explicit. (Miliša, 2008). According to Kellner symbolic value in a modern global society, have technical media, and the value given only the integration of the specific contexts of action and taking roles in society. From this standpoint it is evident understanding of the media that not only (dis) functional but also symbolic role (Tolic, 2010). In what way will have a symbolic value (and that) the role is evident from the relationship between media users (receiver-individual) and the results of the use of media technologies, which affect awareness and behavior of young people (Miliša, Tolic, Vertovsek, 2009). This page is primarily symbolic culturally conditioned, in every socio-cultural context of specific uses and meanings of symbols in society (Cassiere, 2010, 36).

On the functional aspects of the media to get the meaning of the symbols, which affect the construction of personal identity and belonging to social groups (Kellner, 1999, 359). Specifically, it can be seen in the example of the use of mobile phones in search of ever owning the latest computers and software, etc., which can develop distortion symbolic image values, especially among young people with the question: "Tell me what type of Mobiltel belong and I'll tell you who you are "(Miliša, 2008, 45). Another important aspect in the analysis of media culture, as we have previously stated, in symbolic interactionisme, which analyzes the role of symbols in society (Mead, 1988). At the heart of symbolic interactionisme is the idea that "the social reality of people symbolically constructed reality (Luhmann, 1996, 1997). Here one gains the ability to communicate in a collective symbolic action. (Hepp, Krotz, 1999, 35) understanding of the symbolic action of people, cultures can be treated by (i) as a result of the symbolic action of media culture (Kellner, 1999, 269).

French sociologist Pierre Bourdieu and his philosophy of simbolic paradigmatic form provides the basis for understanding human behavior (Bourdieu, 1970, 25). To keep up with Bourdieu's point of view understand the meaning of the development of media culture in the school curriculum is necessary to explain the meaning of terms "field" (Fr. le champ) is a term that means the place in which to implement the process of education and of institution ( school, preschool), but also for inter and extracurricular activities. (Bourdieu, 1970, 25). Despite their differences, the actors in education (fr. Agents-in this case, experts, educators and parents) have the same fundamental interests (Bourdieu, 1970, 45). Otherwise, when there is no critical reflection and a clearly defined goal, it happens that the media "brought up". Therefore, according to Bourdieu in this space is created called. arena in which the individual (in this case-the child-learner) is fighting to change or mirroring force field (Bourdieu, 2007, 45). Then a new (innovative), the media often (downloaded) a manipulative role. Symbolic interactionisme and cultural studies is pervasive, though not explicitly.

A different review of the issues of media culture during the last two decades have passed (the article mentioned above) called. "Cultures Studies - Cultural Studies. They are characterized by the fact that they rejected the functional approach to media culture: Culture is not a system or program that is (necessarily) integrated (a) in the company. Most research in 
the field of cultural studies media and the broader aspects of culture are analyzed in the desired symbiosis. (Hepp, Krotz, Thomas, 2009, 9). The media are also an expression of society where they reflect similar problems as in reality (Bourdieu, 1970, 25).

Douglas Kellner is one of the most critical analysis of media representatives. He made an effort to establish a connection between the Frankfurt School and Cultural Studies (aka Cultures Studies) (Kellner, 1999, 355). He took into account both approaches and their relationship meaningful relationship. On the one hand, tried to distinguish the role of media in relation to the concept of power, on the other hand analyzing the cultural resources to shape, change and / or transform the identity of an individual in a media environment.

Whether it is a cultural studies and the Frankfurt School, both approaches have realized that culture and communication are inextricably linked. All culture is transmitted through communication, each communication through culture, especially through the media culture. In this context of media culture becomes a "carrier" and the symbolic value (Bourdieu) called. field in which the transformation takes place value. Culture and communication can only exist together (Kellner, 1999, 351), a media research this relationship can be analyzed through a combination of theories of cultural studies and critical theory (Kellner, 1999, 356). This raises the question of how media can contribute to making the recipient (child-student and / or a parent, teacher) can help the media attributed to eligible educational significance? From this spectrum to put additional questions: how media culture contributes to the ability of students to know to live in a "cyber society" and the way the media culture receives the (new) meaning? This updated Kellnerov (1999) proposal for the revision of standards and norms of meaning, which are mediated through the media culture. That is the essential prerequisite for the development of media culture and media education, which should be integrated into school curriculum. Cultural studies are based on an understanding of communication. According to this theory, an individual living in both theories: in a world of (non) decode media icons in the other person understands itself as a "communicative identity that constructs its own interaction in the digital culture (Kellner, 1999). Therefore, it can be argued that symbolic interactionisme and cultural studies created by the media and communication theory, which on the one hand based on the same assumptions, (and this is the construction of meaning) and, on the other hand, supplemented with media language and situational effects. Only through both theory can adequately explain the social and media development.

Cultural industry can never fully predict the content and the symbolic value of "cultural products" (Winter 2000.45). The current boom in media term culture of culture and politics of Schmidt (1994) is "a significant indicator of social development from the domination of material things to the domination of knowledge" (Schmidt, 1994.33) This helps the development of the concept of culture "which seeks not only the appearance of the phenomena, than programs for socially relevant products "(Schmidt, 1994, 55). For him, the media culture is important for "thematic examination, evaluation and normative assessment of basic social dichotomy" (Schmidt, 1994, 55). Schmidt approach to diversification, globalization and cultural content segmentation seeks to combine the developments that occur under the influence of new media, especially from the perspective of network communication, which will be crucial for the development of media culture. Schmidt that raises the question of how "culture creates virtuality" (Schmidt, 1994, 55). The development of new media wakes up "fears" and "hope" of euphoria because of the technical and cultural progress and the trend among young people "to be IN and / or COLL" with the estate of sophisticated media "items" (Miliša, 2008). Network communication, for example through Facebook is becoming the main tool and / or so. -Bourdieu's "field" and to organize demonstrations. The fundamental question is that the culture in this context created by the media? Because Kellner media culture sees as "an instrument of domination" (Kellner, 199, 171) This understanding should be understood from the standpoint of the development of media culture and the so-called. the phenomenon of cyber-society.

\section{Media Culture: a formative part of the phenomenon of media education for the development of school curriculum}

Media culture is articulated at various levels, especially in the school curriculum through media education. This assumes an empirical approach to the study of media culture in everyday (school) practice (Reckwitz 2005, 96). Discourses are developed through practice in which they acquire a certain knowledge (Foucault, 1996). The media are part of everyday life and is increasingly becoming a major agent of socialization. They can facilitate and aggravate the communication. Already in early childhood and youth, the media covers issues of social life and a powerful influence on shaping personal life, so that education and upbringing in the school takes a deeper and more direct than before. Consequently, integrated media workshops with the media education in primary schools as a prevention of media manipulation (Miliša, Tolic, 2009) and prevention project, "Ten days without a screen-apstinention ten days of the Media" (project leader prof. Dr. Zlatko Miliša). All stakeholders in the school environment must recognize their specific media functions, not only in education but also education. Reckwitz (2005) analyzed the social and technical 
perspectives of the development of the media culture for the future development of the school and the identity of students with positive social values and orientation (Reckwitz, 2005, 33).

I would single out the following principles for the current school development is a part of media culture and media education.

- Innovation: The development of media is typically a constant renewal and meaningful technical and service.

- Integration: This opens the possibility that at any time elect some of the different forms of media, and that they are properly reflex-critical manner and practice of education (Tolic, 2010)

- Interactivity: Interactivity in the use of the media means of better understanding of the text items, film or sound to your own media formats offer. (Tolic, 2010)

- Experience: Impressions that are transmitted through the media are always realistic. Thus, "virtual reality" simulated reality the non-media 3D in the field of visual, sound and feeling. Often the boundaries between real and media-centered and meaningful sensory impressions and experiences are becoming blurred (Schimdt, 1994).

- Internationalization: versatile function of communication networks, changing social structures. For example, groups that feel that they belong together, no longer depend on geographical proximity. Appear to be new media, facebook groups. On the other hand, the versatility can be seen as an opportunity for the implementation of E Learning.

Media education should be orientated, direct and manage the basic principles (Miliša, Tolic, 2009; Tolic, 2010). Relevant, self-determined, creative and socially-responsible action and behavior under the influence of the media is linked to certain conditions: the life situation and communicative environment for children and adolescents, their needs and emotions, their knowledge and experience as well as their level of ability to form symbolic value (Schmidt, 1994). Whoever on the basis of their knowledge and experience can be estimated from information manipulation in their various forms will be with the media to behave more responsibly and more independent than someone who does not possess such knowledge. In other words, a greater awareness about the negative impact of the media, the less chance for his manipulative actions (Miliša, Tolic, 2009).

\subsection{The orientation of the experiences and activities as the principle of media education and media culture in school} curriculum

Media education for children and youth to create opportunities for action and experience. In this sense, orientation to the experience and activities are considered the basic principles of media education and media culture (Reckwitz, 2005). Orientation on the experience means that through media education should be present the feelings which excite the media. Orientation to the activity relates to the fact that media education should be focused on (current and future) action, eg in the form of active process of problem solving, decision making, evaluation and creation. Based on this orientation it is about encouraging children and young people in using the media to handle the media influences the differentiation and analysis of media expression, as well as in media production in order to participate in the creation of media culture. Media education is not just a school assignment. He just acquired in the family, social and cultural work with children and young people and in media institutions. Media education can be successful only when the society and create a policy framework conditions that lead to the formation of the media environment suitable for children and youth. Media education requires accountability of all involved in the educational process.

Social and cultural work with children and young people implies expansion of cultural opportunities and possibilities for action. Many activities in this area as well as voluntary participation offer good opportunities to develop creativity. From this point of developing a general media competency in terms of know how to live with the media in modern society, technology and globalization.

Media and educational work in school consists of three main roles:

a.) Use of media for different tasks: The goal is to make a variety of media deals, and the ability to create a critical selection and evaluation of information (Reckwitz, 2005; Tolic, 2010).

b.) Insight into the mode of action and conditions of the media:

In talks on outstanding issues, which were largely ignored, as a matter of personal taste and preferences, pleasures, are gaining more importance in pedagogical work. (Reckwitz, 2005; Tolic, 2010, Winter, 2000). Young people should be familiar with how different types of programs (eg, magazine, newspapers for teenagers, soap ...) is so different forms of presentation, as a prerequisite for the proper functioning (Cassirer, 2010; Reckwitz, 2005; Tolic, 2010, Winter, 2000). Critical analysis requires knowledge of the conditions of media production, distribution and access to edit the editorial policy (Winter, 2000).

c.) Practical and creative media work: The goal is to expand the possibilities of expression and creation to build the 
capacity for accurate perception and the social responsibility of media and media users. Participation in school newspapers, photography exhibitions, documentaries, news reports, or video journals, children and young people have the opportunity to articulate their ideas, using various media and thus can spread outside the school climate. They then realize that reality is always in the media "produced on" and so subjectively shaped and oriented under the influence (corporate) interests. At the level of the game, for example, in creating own computer games, it is desirable to work. Practical and creative media work is particularly suitable for the promotion of forms of cooperative learning. Thus, students in group work learning to occur and media products that individuals are instructed to cooperate with others (Baack, 1973). Through the division of roles and tasks they discover their abilities, aptitudes and skills. This is particularly important to work in extra-curricular and extracurricular activities. Media education and media culture must foster the ability of active and accurate perception. There are key activities that should complement one another: stages, which are more oriented to their own creation and production of media, one that is primarily targeted to the processing of information, analytical reflection and experience (Lundby, 2009).

Media education and media culture should include informal, extracurricular, and public area. The school said a variety of environments authentic work situations and tasks. Interviews with representatives of the media "house" and collaboration with experts facilitate the acquisition of necessary skills (Hepp, Krotz, 2010). Given that the media have become indispensable factors in teaching, school culture must be developed with the help of the media, but with a reflexive-critical aspect. From this we can develop favorable conditions in different areas for greater cooperation between schools and families (Hepp, Krotz, 2010).

The analysis and evaluation of media effects and influences can be combined in various media content (Hepp, Krotz, 2010). Products from comics to advertisements, from the video clip to the computer program should be the focus of educational attention. Development and construction of media pedagogy at the media education and media culture in schools should be seen through two approaches: the more use of media as aids in teaching in terms of media didactics is media education and media culture as a means of training for critical-productive behavior with the media and their messages. Schools must prepare for these tasks through enhanced coordination of media and educational activities within the curriculum as well as through systematic coordination and cooperation with extra-curricular activities. A good example of cooperation between school-teacher-parent-student project is visible from ten days without a screen-manual / workshop for the development of critical and selective use of three screens in the young (Miliša, Z., Tolic, M., Tudor, G., Drobac, I. 2010). Collaboration between schools and extracurricular partner is necessary. Media education is not tied to a place of learning, therefore, for school. In addition it can not be ignored coordination within the school. Coordination of the school will have to increase and intensify due to the changing demands in the field of management in schools (Schmidt, 1994).

Media and educational work in schools in some areas related to the accessibility and availability of special equipment. Given scarce resources, school leaders should constantly work on technical updating of the school. In the technical field of media development leads to rapid obsolescence of existing equipment.

Media pedagogy with the development of media culture in schools should be understood as a general pedagogical, and not as an additional task. For this goal to be enhance professional, academic discussion and collaboration within the school. Media pedagogy with the media culture and media education should become a reference point for the discussion of the basic goals and tasks of the Modern School (Miliša, Tolic, Vertovsek, 2009).

What is required is a permanent training of teachers, professional staff and parents. Teachers, associates and parents are finding that their students more familiar and / or use electronic media than they do. They are bound to meet with the media experiences that children and young people bring with them to school. The goal of upbringing of the educational prevention project for teachers and parents in the field of media education should be based for the adoption of media competencies and capabilities to use new technology, where so downloade responsibility for education with the media and young people. For the purposes of methodological aspects of learning and mastering the tasks of media education is necessary to develop the technical skills and the ability to "processing" of media products, to scientific and public debate on the use of media and media effects could be systematically monitored. (Schmidt, 1994).

Educational policy and school curriculum regarding the professional and educational impact of the spread of media and media influence should respond quickly and comprehensivelly, and should improve conditions for working with modern media and implement media education and develop a media culture in schools. We should use electronic media in learning more intensively than ever before. Media education and media culture should be part of the general and I continued educational activities of schools. It should be implemented in the school experiences of other European countries (Germany, France ...) in shaping the media landscape and media pedagogy. 


\section{Conclusion}

Analysis of culture media revealed the interest of the media industry and / or power of some of the media to change the culture affect the public, especially children and youth. Media culture and cultural industry transformed the culture and as such it is necessary to understand (i) the consumer society. Broader understanding of media culture, media culture is treated as an overall phenomenon, which is specified at the level of media production, media content, their reception, but the (political) control, conflict, and identification. On the other hand, every culture has permeated the circulation of meaning. New information technologies change the habits and behavior of individuals, especially young people. With the development of innovative media and the growing need for the development of media culture, especially in the process of education. The media can facilitate communication and aggravate. All culture is transmitted through communication, each communication through culture, especially through the media culture. In this context of media culture becomes a "carrier" of symbolic value. Media culture has to be in self-regarding media education and thus enable the successful development of the process of education in the so-called. cyber-society (society). No media education, which implies the adoption of media competence alone is not able to develop culture media core competencies. Only such a culture media with the media education can develop students' critical-reflective attitude. Neither theory starting from Frkankfurtske school, symbolic interactionisme and cultural studies in the analysis can not be completely "justify" the development of media culture, if they are not analyzed outside the context of media education in the discipline of Media Pedagogy. Media culture, today, when media competence becomes more important than the media and technical literacy, should be given adequate time and space in school for a critical attitude towards the media. Media culture should contribute to raising students' cultural, introducing cultural facts relating to the media. The school increasingly ceases to be a source of information because it is becoming more successful in competing television, internet and other means of mass communication. Croatia should primarily provide important framework conditions for the school media work: appropriate to the agreed plan and program of instruction is a prerequisite for media education and media culture in schools are an integral part of teaching and general education (school curriculum). Film art and / or culture is only one segment of media education. Media pedagogy with the development of media culture in schools should be understood as a general pedagogical, and not as an additional task. Media education goes beyond the media culture and media literacy. For these reasons it is justified to require pedagogical education of the subject for the media in primary schools.

\section{References}

Baacke, D. (1973). Kommunikation und kompetenz- Grundlegung einer Didaktik der Kommunikation und ihrer Medien, Juventa Verlag, München.

Bordieu, P. (2007). Zur Soziologije der symbolischen Formen, Shurkamop Verlag, Sttutgart.

Cassirer, E. (2010). Philosophie der symbolischen Formen. Erster Teil: Die Sprache, Meiner Verlag, Hamburg

Gramsci, A. (1987). Marxismus und Kultur. Ideologie, Alltag, Literatur. Hamburg: VSA.

Faßler, M. (2001). Netzwerke, München: Fink.

Focault, M. (1996). Wie wird Macht ausgeübt? In Focault, Michael/Seitter, Walter (Hrsg.), Das Spektrum der Genealogie. Frankfurt am Main: Philo, pp. 29-47.

Habermas, J.(1990). Strukturwandel der Öffentlichkeit. Untersuchung zu einer Kategorie der bürgerlichen Gesellschaft. Mit einem Vorwort zur Neuauflage 1990. Frankfurt/Main: Suhrkamp.

Hall, S. (1993). Culture, Community, Nation. In: Cultural Studies 7, 3, pp. 249-363. http://dx.doi.org/10.1080/09502389300490251

Hartmann, M. (2008). Domestizierung 2.0: Grenzen und Chancen eines Medienaneignungskonzeptes. In: Winter, Carsten/Hepp, Andreas/Krotz, Friedrich (Hrsg.): Theorien der Kommunikationswissenschaft. Wiesbaden: VS, pp. 402-416.

Hepp, A. (2010). Cultural Studies und Medienanalyse. Eine Einführung. Dritte, überarbeitete und erweiterte Auflage. Wiesbaden: VS.

Hepp, A., Krotz, F., \& Thomas, T. (2009). Schlüsselwerke der Cultural Studies: Einleitung. In: Hepp, Andreas/Krotz, Friedrich/Thomas, Tanja (Hrsg.): Schlüsselwerke der Cultural Studies. Wiesbaden: VS, pp. 7-17.

Hepp, A., \& Krotz, F. (2010). Theorien der Kommunikations- und Medienwissenschaft. Wiesbaden: VS, pp. 49-63. 
Kellner, D. (1999). Medien- und Kommunikationsforschung vs. Cultural Studies. Wider ihre

Trennung. In: Bromley, Roger / Göttlich, Udo / Winter, Carsten: Cultural Studies. Grundlagentexte zur Einführung. Lüneburg: zu Klampen: pp. 341-362

Livingstone, S. M. (2009). On the mediation of everything. In: Journal of Communication 59, 1, pp. 1-18. http://dx.doi.org/10.1111/j.1460-2466.2008.01401.x

Loebl, E. (1903). - Kultur und Presse. Von Emil Löbl. - Leipzig: Duncker \& Humblot, VIII, 291 pp. 8

Luhmann, N. (1997). Die Gesellschaft der Gesellschaft. 2 Bände. Frankfurt/Main: Suhrkamp.

Luhmann, N. (1996). The Thory of Communication, Loet Leydesdorff, Amsterdam Lundby, K. (2009a), Introduction: >Mediatization< as a Key. In: Lundby, Knut (Hrsg.):

Mediatization: Concept, Changes, Consequences. New York u. a.: Peter Lang, pp. 1-18.

Lutze, P. (2004). Die Matrix_Hypothese- Para-abstrakte Orinetierung in einer erfundenen Wirklichkeit, Philosophische Fakultät der Westfälischen Wilhelms- Universität, Münster.

Mead, G. H. (1988). Geist, Identität und Gesellschaft. 7. Auflage. Frankfurt/ Main: Suhrkamp.

Merten, K. (1994). Evolution der Kommunikation. In: Merten, Klaus/Schmidt, Siegfried J./Weischenberg, Siegfried (Hrsg.): Die Wirklichkeit der Medien. Eine Einführung in die Kommunikationswissenschaft. Opladen: Westdeutscher Verlag, pp. 141-162.

Meyrowitz, J. (1995). Medium Theory. In: Crowley, David J./Mitchell, David (Hrsg.): Communication Theory Today. Cambridge, Oxford: Polity Press, pp. 50-77.

Meyrowitz, J. (1987). Die Fernsehgesellschaft. Wirklichkeit und Identität im Medienzeitalter.

Weinheim, Basel: Beltz

Miliša, Z. (2006). Manipuliranje potrebama mladih, Markom, Zagreb.

Miliša, Z. (2009). Vom Skeptizismus zu den Studentendemiostratione: damals und heute, Studenten Demonstrationen: Bundesbildungministerin Prof. dr. Annette Schavan äussert Verständnis für einige forderungen der demosntrierenden Studenten, GmbH, Stuttgart

Miliša, M., Tolić, M., \& Vertovšek (2009). Mediji i mladi- prevencija ovisnosti o medijskoj manipulaciji, Sveučilišna knjižara, Zagreb

Reckwitz, A. (2005). Kulturelle Differenzen aus praxeologischer Perspektive. Kulturelle Globalisierung jenseits von Modernisierungstheorie und Kulturessentialismus. In: Srubar, Ilja/Renn, Joachim/Wenzel, Ulrich (Hrsg.): Kulturen vergleichen. Sozial- und kulturwissenschaftliche Grundlagen und Kontroverse. Wiesbaden: VS, pp. 92-111.

Schmidt, S. J. (1994). Kalte Faszination. Medien, Kultur, Wissenschaft in der Mediengesellschaft. Weilerswist: Velbrück.

Tolić, M. (2011). Pour une pédagogie des médias appliquée - aussi dans la formation professionnelle, Medijska kultura, 1, Crna Gora

Tudor, G., Miliša, Z., Tolić, M., Vertovšek, N., \& Drobac, I. (2010). Deset dana bez ektana- deset dana apstinencije o medija, MEP, Zagreb.

Žanić, J. (2008). Semiozom stvoren svijet:Cassirer - Goodman, Filozofska istraživanja, 109 God. 28 (2008) Sv. 1 (pp. 107-116), Zagreb

Winter, R. (2000). Was ist populäre Unterhaltung? Die Perspektive der Cultural Studies, in: medien praktisch. Zeitschrift für Medienpädagogik, Heft 4, pp. 21-26. 